\title{
Hybrid Bamboo and Batik Handicraft Development as Creative Tourism Product
}

\author{
Rudy Pramono $^{1 *}$, July Hidayat ${ }^{2}$, Cherry Dharmawan ${ }^{3}$, Juliana ${ }^{1}$ \\ ${ }^{1}$ School of Hospitality and Tourism, Pelita Harapan University, Tangerang, Banten 15811, Indonesia \\ ${ }^{2}$ School of Design, Pelita Harapan University, Tangerang, Banten 15811, Indonesia \\ ${ }^{3}$ School of Design, Computer Indonesia University, Bandung 40132, Indonesia
}

Corresponding Author Email: rudy.pramono@uph.edu

https://doi.org/10.18280/ijdne.160515

Received: 22 March 2021

Accepted: 30 September 2021

\section{Keywords:}

bamboo batik handicraft, prototype, creative

tourism product

\begin{abstract}
A new bamboo-based industry has been developed to meet market demands. Traditional crafts practiced by local communities provide a substantial contribution to the legacy of intangibles. This research situates traditional bamboo handicrafts in Yogyakarta and emphasises their importance as well as concerns for their influence. The research goal is to determine the amount of consumers interested in bamboo handicraft products marketed publicly as tourism products and to evaluate the entrepreneurial landscape. The accidental sampling methodology was employed with 76 respondents, and the research method included qualitative and quantitative descriptive methods such as observation and semistructured interviews. To comprehend the study outcomes, the primary respondents of Sahabat Bamboo from the data analysis approach using SPSS analysis provide descriptive data defining the respondent's condition. The market research analysis shows that bamboo batik handicraft has potential in demand; most respondents like bamboo batik handicraft products.
\end{abstract}

\section{INTRODUCTION}

Indonesia has 74,954 villages throughout the archipelago, where various challenges and problems are faced amid a beautiful and harmonious life [1]. The advantages of the countryside include beautiful natural scenery, fresh and pollution-free air, traditional food with local flavours, distinctive local culture and wisdom, and many other advantages that cannot be found in urban areas [2, 3]. The bamboo industry can generally be divided into five catalogs: food, manufacturing industry, ecotourism, energy and construction. In addition, eco-efficiency, carbon footprint and water footprint are also discussed during the development process [4]. A global organization for economic cooperation and Development (Organization for Economic Co-operation and Development or OECD) with 36 members raised the issue of including 'environmentally friendly' considerations in regional trade agreements. More and more countries are using trade agreements to cooperate on environmental issues by including part or even a chapter on environmental awareness in their regional trade agreements [5]. A tourism product is a complex set of different physical resources, activities and services. By purchasing this combination of natural resources, activities and services, guests are buying a desire for experiences, for certain experiences. It can be said freely that it is leading, bringing instruments in the business and tourism industry $[6,7]$. As an important natural resource, bamboo has an important role in poverty alleviation due to its natural nature and the potential economic benefits of processing bamboo products. Many researchers have studied the ecological functions of bamboo [8-10]. In addition, the development of the bamboo industry is also an important way to promote economic growth and increase the income of people in many countries around the world. In the craft industry (a combination of arts and crafts) in Indonesia, bamboo is an endemic material to the archipelago that has the great economic potential to enter the export market of countries that apply these 'environmentally friendly' considerations because (1) it does not damage the environment (environmentally friendly), (2) has a relatively short production period of 3-5 years, and (3) is multi-functional (versatile). The beautiful scenery of the bamboo forest has an aesthetic value. Through the development of ecotourism can increase the income of local residents [11]. Ecotourism provides visitors with spiritual enjoyment, helping them experience the beauty and harmony of nature. The development of the bamboo craft industry can be developed in Indonesia because Indonesia has a large supply of raw materials (data from the Ministry of Environment and Forestry is 2.1 million hectares consisting of 700,000 hectares in forest areas and 1.4 million hectares in agricultural areas). Plantation). Indonesia has 160 species of bamboo (Ministry of Environment and Forestry, 2015) and 88 species of which are bamboo species that only grow or have native habitats in Indonesia (endemic to the archipelago) (Kresnarini, Hesti Indah from the Director-General of National Export Development, Ministry of Trade RI, 2011). Indonesia is already a member of the international network on bamboo and rattan trade (INBAR). In Indonesia's exports, forest products (bamboo is classified as a non-timber forest product) are in 5th place, and handicrafts are in 7th place for potential commodities. Based on 2015 data, Indonesia is the thirdlargest exporter of bamboo and rattan products in the world (7\%), after China (40\%) and the European Union (8\%), with an export value of 6 trillion (Director of Social Forestry and Customary Forest Business Development), Ir. Masyhud, MM 
in Merdeka, November 25, 2015). While the latest statistical data in 2018 from the Ministry of Industry (Kemenperin), the export value of processed wood, bamboo, and rattan goods reached 3.37 trillion. Statistical data shows a decline, so synergistic cooperation from various parties is needed. In this case, the government, educational institutions such as UPH, the bamboo craft industry, and the crafts community to develop the commercialization of Indonesian bamboo. All of the statistics above illustrate that bamboo crafts have great economic potential in the export market. Still, in terms of design innovation and marketing strategies, they are relatively underdeveloped compared to Japan, which also has a traditional craft culture, especially bamboo. This is influenced by (1) the absence of formal vocational education in bamboo crafts, (2) the lack of mastery of manufacturing techniques assisted by adequate tools to produce more neat, precise, and standardized bamboo products, (3) the absence of government support in subsidies. Skills education derived from local wisdom (in a country with an old bamboo culture such as Japan, the government provides subsidies for learning traditional weaving techniques to protect traditional technology derived from local cultural wisdom) accompanied by the provision of official expertise certification from the government, and (4) the cooperation of various parties, namely the government, the private sector, the world of education and the bamboo craft industry to publicize and market bamboo products has not yet achieved a good synergy. Thus, the logical background for the commercialization of IndonesianJapanese batik bamboo is proposed: first, to transfer knowledge about (1) innovations in bamboo-batik craft designs that have been made during 2017-2018, in the creation of bamboo crafts that combine culture local Beppu (bamboo centre in Japan and Bantul (Yogyakarta), including local techniques and materials, (2) production system strategies to produce neatness, precision, and standardization of production stages, (3) publication and marketing strategies from Japanese bamboo artisans who successfully opened the market bamboo crafts in Europe (France, Denmark, and Sweden) and New York when synergizing cooperation between educational institutions such as bamboo schools and bamboo museums with the government (Beppu city government), Japanese NonGovernmental Organizations (NGOs) in foreign countries, and community of bamboo craftsmen. Second, to assist the partners of Sahabat Bamboo craftsmen in developing publication strategies and $\mathrm{n}$ marketing of bamboo crafts through design innovation (a combination of bamboo with batik), unifying product narrative concepts in design and marketing to develop local markets and enter export markets. Yogyakarta is one of the five largest bamboo craft centres in Indonesia and West Java, Central Java, East Java, and Bali. In the province of D.I. Yogyakarta itself, the export value of Yogyakarta's creative industries in 2014 reached 2.8 trillion (Bisnis Tempo, September 16, 2014). Small business partner 'Sahabat Bambu' is a bamboo industry that moves upstream to downstream, starting from nurseries, preservation, architecture, construction (including panels, parquet flooring, and laminated bamboo), bamboo furniture, and crafts. For this reason, a collaboration between the government, UPH, small industry 'Friends of Bamboo,' and the craftsman community working with 'Friends of Bamboo' is needed so that Sahabat Bambu's domestic market is more developed and can penetrate the export market. Small industries with innovative products will advance the regional and national economy and ultimately contribute to the country's foreign exchange when they penetrate the export market. Businesses (a combination of bamboo arts and crafts) are generally managed individually or in groups with the scale of home industry, with labour for family members and limited capital. Collectors collect bamboo craft products from one family to another and act as sales intermediaries between the craftsmen or artisan communities and the shops or galleries. Thus, handicraft production is generally not managed professionally because it uses standardization of production stages and product quality. Because it is often categorized as an art item, 1 type of bamboo craft is often made with non-uniform material quality, size, and finish. It does not meet consumer expectations. In this case, the bamboo craftsman 'Sahabat Bambu' can learn from the production method of Beppu bamboo craftsmen in Japan, which applies standardization of production stages, material sizes, and products and tools can produce products in large quantities with relatively uniform quality. The formulation of the problem in this research is How to change a unique production method with a limited number of productions (custom made such as works of art) into a mass-production system that has standardized production? The marketing of Sahabat Bambu handicraft products is still limited to the areas of Java and Bali. It is still 5\% of their total sales of bamboo products (preservation, building, construction, furniture, and handicrafts), while other divisions have succeeded in penetrating the export market (Malaysia, Maldive, France, Australia). On the other hand, the potential for the export market for bamboo handicrafts is quite large (2018 data from the Ministry of Industry states that the export value of wood, woven bamboo, and rattan products reaches 3.37 trillion), and Yogyakarta is one of the centres of bamboo handicrafts in Indonesia. When the potential is great, but the market is not managed properly, the productivity of the craftsmen is minimal, and to earn money, the craftsmen change jobs between being craftsmen and construction workers, and so on, so that their expertise in the field of bamboo crafts does not develop because they are also not focused. This is not good for the nation's competitiveness in the bamboo handicraft industry in the international market, while from the data above, we know that Indonesia is the third-largest bamboo exporter in the world after China and the European Union. We must develop the expertise of Indonesian bamboo craftsmen so that they have a real contribution to contribute to the country's foreign exchange from the creative industry sector. The formulation of the problem in this research is What are the commercialization efforts (publication and marketing) that must be carried out to be able to develop the domestic market and penetrate the export market, starting from the Asian export market? Commercialization is the process or cycle of introducing a new product to the market. Commercialization itself is just one of the stages in a large cycle of new product development (product development), which in total consists of 7 stages as follows: (1) understanding consumer needs, (2) creating product concepts, (3) design, (4) developing prototypes, (5) making final designs and pilot products, (6) product commercialization, (7) product maintenance, and (8) product development/expansion/diversification (adaptation of product development stages from Pellikka et al. [12, 13]. The art commercialization movement, although until now has become a debate because it is considered to reduce the value of art, but in the history of craft art, it has occurred through the arts and craft movement, precisely to increase the selling value of handicrafts. The previous condition is similar to what is happening in Indonesia today for bamboo crafts, where 
handicrafts become the consumption of disposable objects in the culture of everyday life of the general public. Still, through a movement that combines arts and crafts (kriya), handicrafts become the consumption of the urban bourgeoisie (uppermiddle class with a bourgeois lifestyle - able to buy art for visual enjoyment, inner dialogue, investment, and a mere lifestyle). Previous research on the commercialization of traditional crafts from South and Southeast Asia [14]. They highlight the relationship between the development of the tourism industry in an area and the development of the traditional craft industry. Their research explains the emergence of bamboo craftsman villages in Yogyakarta, which the D.I inaugurated. Government. Yogyakarta has become a tourist village for bamboo crafts (example: Brajan Bamboo Craft Village and Tunggak Semi bamboo craftsman community in Malangan Tourism Village, Sleman). However, the results of [14] were obtained based on the literature study method. At the same time, the research we carried out was a lesson from direct experience in developing bamboo handicraft designs into bamboo crafts (2017-2018) and currently studying the commercialization of bamboo crafts. One of the added values of this research is the specification of commercialized traditional crafts, namely the IndonesianJapanese cultural hybrid design craft of bamboo-batik. Until now, there has been no publication on the commercialization of bamboo-batik crafts. In Indonesia, most bamboo plantations are abandoned due to low productivity, low economic value, and dark, dirty, and shabby conditions where many insects live. Bamboo is a large woody grass group in the Poaceae family [15]. This ancient woody grass is found in tropical, subtropical and cold climates [16]. They are very diverse plants with the capacity to adapt to extreme climatic and soil conditions. They are found in many world regions and play an important economic role [17]. In the study [18] women prefer this bamboo batik handmade product, according to odd groupings, but there are still some product flaws, and the market price is high. Study [4] stated that several domestically practiced bamboo industries that help increase farmers' incomes and promote economic development. Study [19] stated that economies of scale and product quality are the main inhibiting factors for the successful commercialization of resources. Policy interventions aimed at increasing rural participation in value chains should include eliminating gender stigmatization, providing technical and marketing support to rural artisans, and establishing cottage industries as part of efforts to integrate rural business communities into local tourism.

\section{METHODS}

The study used a qualitative and quantitative methodology that included participant observation and semi-structured interviews [20] - observations and interviews were done in Yogyakarta. In the descriptive research design, the study used a qualitative and quantitative method. The data for this study originated from primary sources, specifically surveys distributed directly to product sales respondents. The researcher acquired the questionnaire from the respondent and had respondents who had never purchased bamboo items fill out a questionnaire. Data collection in the market test was obtained through questionnaires distributed directly to respondents in product sales based on the results of the market trial in Indonesia. Questionnaires were gathered by researchers individually visiting with respondents and handing out questionnaires to those who had purchased or had never purchased bamboo products. The sample technique employed is the accidental sampling technique. In other words, sampling is based on a fixed amount. This sampling is based on the subjects encountered in order to make data collection easier and to ensure that the specified number of samples is achieved, therefore the total number of samples obtained is 76 Questionnaire samples. As a result, the data processing requirements for the SPSS sample analysis tool can be met. The goal of descriptive research data presentation is to examine the profile of the research data as well as the relationship between the variables employed in the study. Descriptive data detailing the respondent's state or condition is useful in understanding the research findings. This study questionnaire has a number of questions. As a result, the SPSS sample analysis tool can meet the requirements for data processing.

The goal of descriptive research data presentation is to be able to see the profile of the research data. Descriptive data detailing the respondent's state or condition is useful in understanding the research findings.

\section{DISCUSSION}

The following are some of the Bamboo-Batik Craft Prototype (see Figure 1).

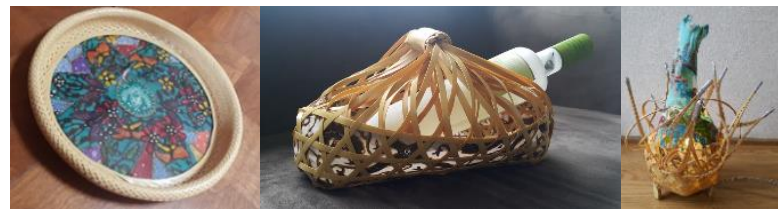

Figure 1. Bamboo-Batik craft prototype

Respondents in the study have characteristics.

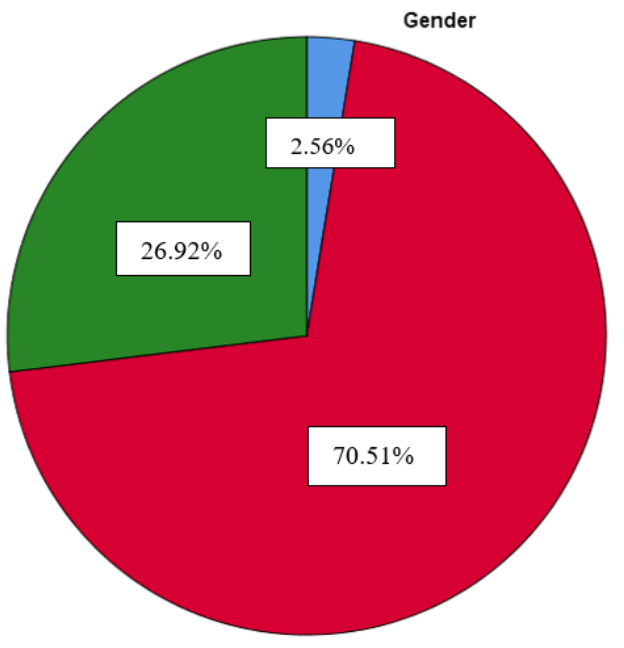

$\mathrm{Q}_{1}$

Figure 2. Gender

Source: Processed Data (2021)

The research characteristics of consist of the gender of the consumers of SABATIK products taken as respondents (see Figure 2). The most common gender is $72.4 \%$ female and $27.6 \%$, male.

The age of the respondents who became the sample of this research ranged from 20-30 years (see Figure 3), there were as 
many as 28 respondents or $36.8 \%$ of the total sample, who had an age of 30-40 years, there were 15 respondents or $19.7 \%$, who had an age of 40-50 years as many as 23 respondents or $23 \%$, and for those who are over 50 years old, 10 respondents or $13.2 \%$. The information above shows that most of the consumers who have bought bamboo products are taken as respondents who are 20-30 years old.

The addresses of the respondents who became the research sample came from various regions (see Figure 4). Most sabatik consumers come from the Jakarta area, with as many as 16 respondents or $20.5 \%$ of the total sample. Furthermore, consumers who have purchased bamboo products at least come from the areas of Balikpapan, Bekasi, North Bengkulu, Denpasar, Denpasar Bali, Depok, South Jakarta, North Jakarta, East Jakarta, Kuningan, Kutai Kartanegara, Klaten, Pemalang, Semarang, Sukoharjo, and Tangerang. which each region only has approximately 1 consumer or $1.3 \%$ of the total sample.

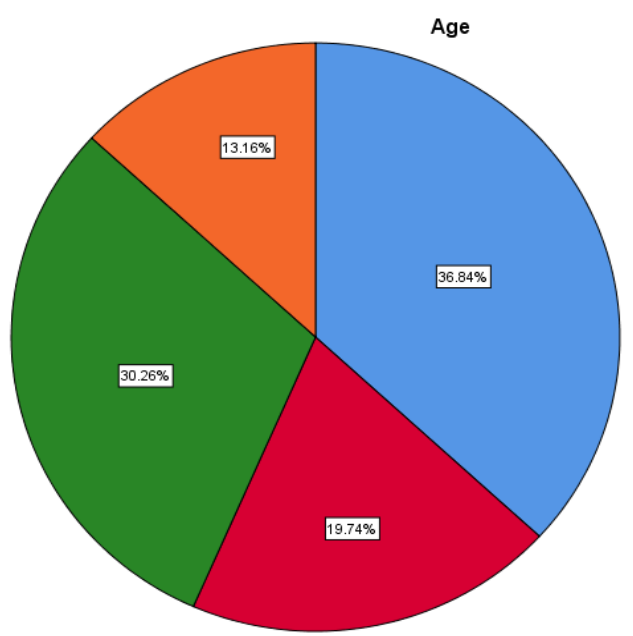

Figure 3. Respondent age Source: Processed Data (2021)
Figure 4. Respondent address Source: Processed Data (2021)

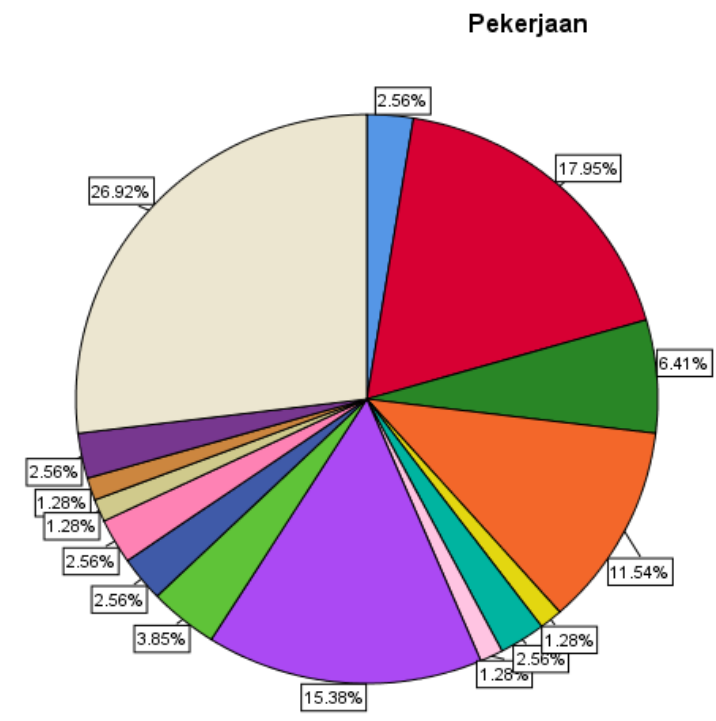

Figure 5. Respondent profession Source: Processed Data (2021)

\begin{tabular}{|c|c|}
\hline & Klaten \\
\hline Bali & Kuningan \\
\hline Balikpapan 1 & Kutai \\
\hline Bandung & kartanegar \\
\hline Bekasi & Pekalongan \\
\hline Bengkulu & Pemalang \\
\hline Utara & I Salatiga \\
\hline$\square$ Bogor & ] Samarinda \\
\hline$\square$ Boyolali & Semarang \\
\hline$\square$ Cimahi & Sidoarjo \\
\hline$\square$ denpasar & Sukoharjo \\
\hline$\square$ Denpasar & $\square$ Surabaya \\
\hline$\square$ Denpasar bali & ¡ $\square$ tangerang \\
\hline$\square$ Depok & $\square$ Tangerang \\
\hline Jakarta & Tangerang \\
\hline Jakarta & \\
\hline $\begin{array}{l}\text { Selatan } \\
\text { Jakarta t }\end{array}$ & gyakar \\
\hline $\begin{array}{l}\text { Jakarta timu } \\
\text { Jakarta Utar }\end{array}$ & \\
\hline
\end{tabular}

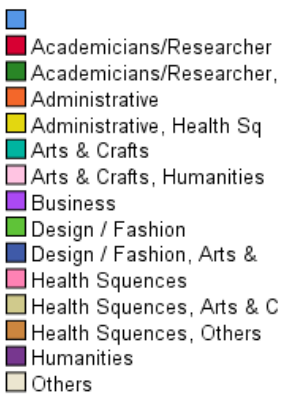

Humanities 
The occupations of the respondents who were the samples of this study consisted of various occupational/professional backgrounds (see Figure 5). Respondents who became the most research sample had a job as a researcher.

\section{Have you ever bought bamboo products?}

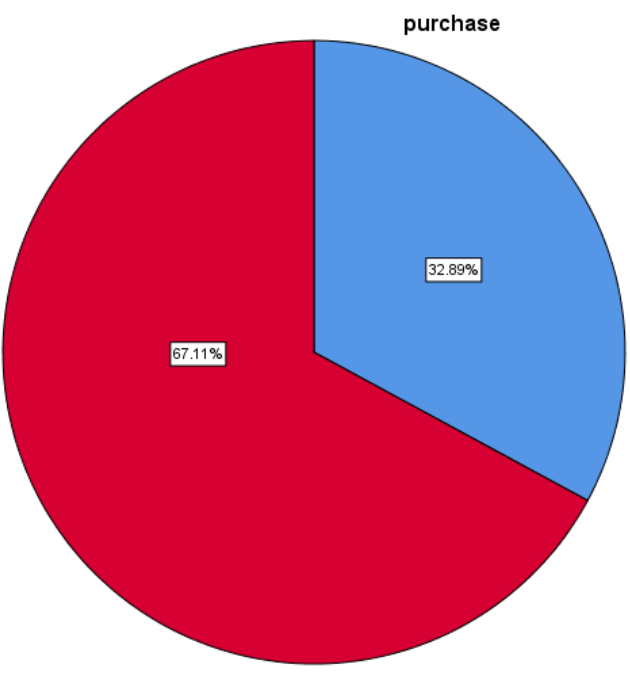

$\square$ No
$\square$ Yes

Figure 6. Purchase bamboo products Source: Processed Data (2021)

It can be seen (Figure 6) as many as 51 or 67.1 respondents have bought Sabatik products, and 25 or 32.9 respondents have never bought Sabatik products from the total respondents.

How important are the following elements to you when purchasing bamboo products? [Product category]

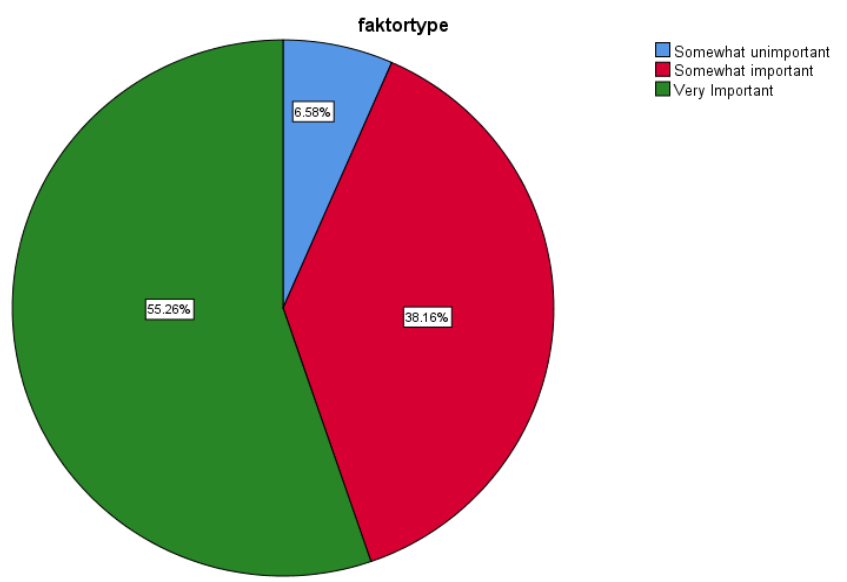

Figure 7. Product type

Source: Processed Data (2021)

It can be seen (Figure 7) that the responses of the 76 respondents, 42 answered very important, 29 answered slightly important, and the remaining five answered slightly unimportant.

How important are the following elements to you when purchasing bamboo products? [Product completion]

It can be seen (Figure 8) the response of the 76 total respondents, 48 answered very important, 22 answered slightly important, and the remaining six answered slightly unimportant.

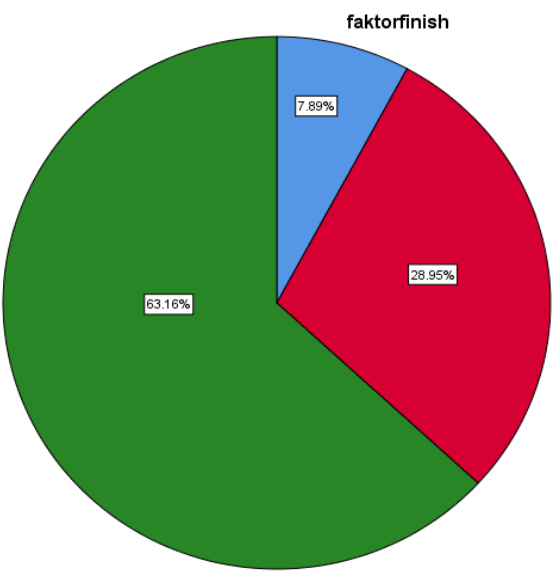

Figure 8. Product finishing Source: Processed Data (2021)

How important are the following elements to you when purchasing bamboo products? [Product calibre] (durable)

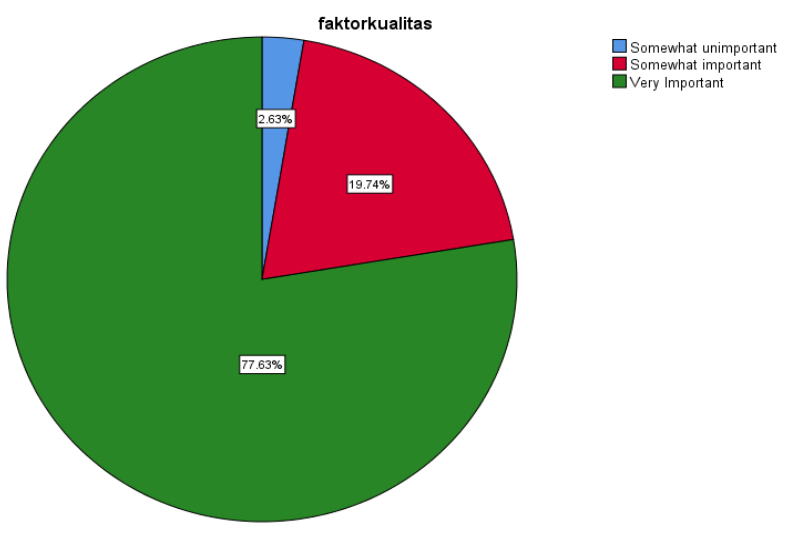

Figure 9. Product quality (durable) Source: Processed Data (2021)

It can be seen (Figure 9) that the response of the 76 respondents, 59 answered very important, 15 answered slightly important, and two answered slightly unimportant.
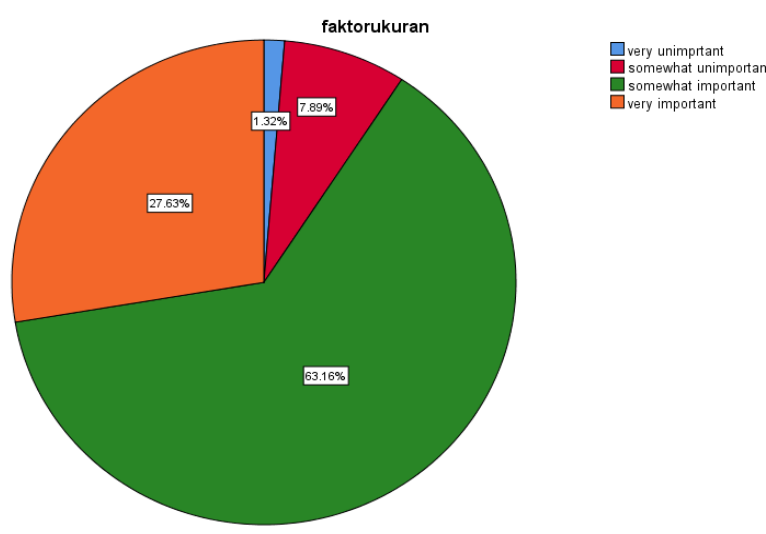

Figure 10. Product size

Source: Processed Data (2021)

How important are the following elements to you when purchasing bamboo products? [Product Dimensions]

It can be seen (Figure 10) that the responses of the 76 respondents, 21 answered very important, 48 answered slightly important, six answered slightly unimportant, and the 
remaining one answered very unimportantly.

How important are the following elements to you when purchasing bamboo products? [Bamboo-specific terminology used]
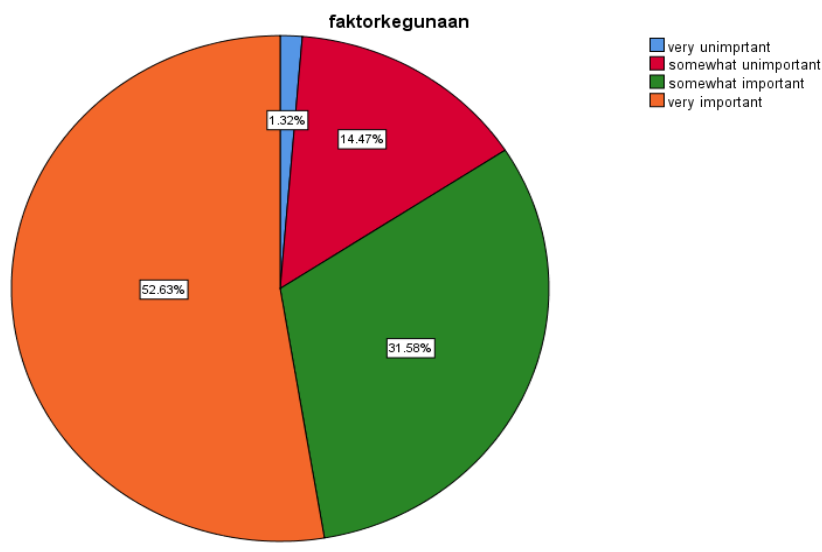

Figure 11. Bamboo specific used Source: Processed Data (2021)

It can be seen (Figure 11) that the responses of the 76 total respondents, 40 answered very important, 24 respondents answered slightly important, 11 answered slightly important and the remaining 1 answered very unimportant.

How important are the following elements to you when purchasing bamboo products? [Product name]

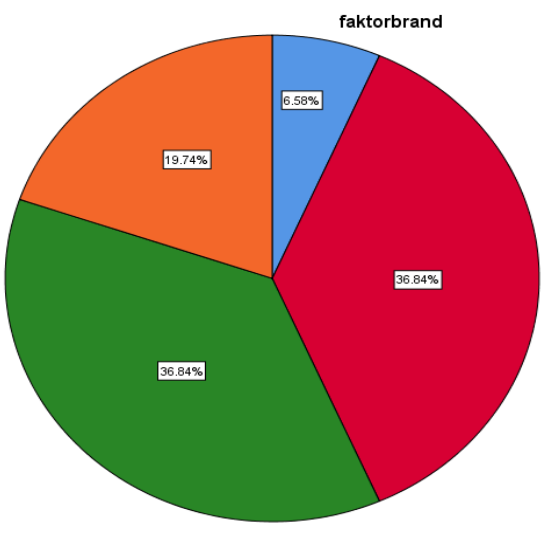

Gerry unimprtant
Gomewhat unimportan
Gomewhat important
very important

Figure 12. Product brand Source: Processed Data (2021)

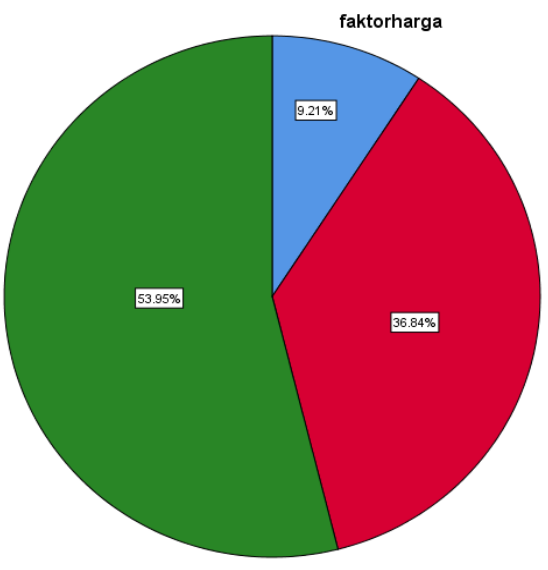

Gsomewhat unimportan
somewhat important 员omewhat impo
Figure 13. Product price Source: Processed Data (2021)
It can be seen (Figure 12) that the responses of the 76 respondents, 15 answered very important, 28 answered slightly important, 28 answered slightly important, and the remaining five answered very unimportantly.

How important are the following elements to you when purchasing bamboo products? [Product cost]

It can be seen (Figure 13) the response of the 76 respondents, 41 answered very important, 28 answered slightly important, and the remaining seven answered slightly important.

How important are the following elements to you when purchasing bamboo products? [Product Showcase]

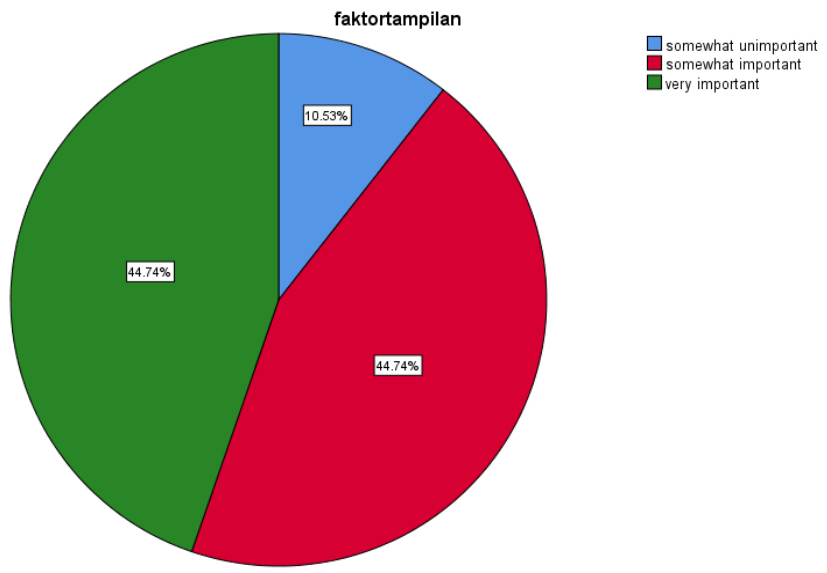

Figure 14. Product display

Source: Processed Data (2021)

It can be seen (Figure 14) the response of the 76 respondents, 34 answered very important, 34 answered slightly important, and the remaining eight answered slightly important.

\section{CONCLUSIONS}

According to the study results, bamboo batik handicraft items have potential and are in demand by the market; according to the market research analysis, most respondents like bamboo batik handicraft products. According to a market research review of odd groupings, women like this bamboo batik craft product. There are still certain product flaws, and the market pricing with the most common gender is 72.4 percent female and 27.6 percent male. Design, material, product quality, function/usage, and pricing are the most important considerations when purchasing a handcrafted item.

Increasing product competitiveness necessitates the development of workforce skills, products, and marketing methods aimed at better hearing the voices of consumers. The development of the bamboo sector as a new economic growth point will be critical in protecting national culture and building the eco-cultural tourism landscape. Furthermore, the cultivation of bamboo resources can assist to support the growth of various linked sectors in a relatively short period of time, boost revenue, reduce farmer poverty, and improve the local environment.

\section{ACKNOWLEDGMENT}

This manuscript is the result of research funded by the Education Fund Management Institute of the Ministry of 
Finance of the Republic of Indonesia with the agreement number PRJ-56/LPDP/2019 with LPPM Pelita Harapan University.

\section{REFERENCES}

[1] Suranto, Soetjipto, B., Wahyono, H., Haryono, A., Rodzalan, S.A. (2019). Community based tourism: Revitalization of villages through bamboo plantation conservation. Humanit. Soc. Sci. Rev., 7(2). https://doi.org/10.18510/HSSR.2019.7239

[2] Tu, S., Long, H. (2017). Rural restructuring in China: Theory, approaches and research prospect. Journal of Geographical Sciences, 27(10): 1169-1184. https://doi.org/10.1007/s11442-017-1429-x

[3] Long, Y., Tu, H., Ge, S., Li, D., Liu, T. (2016). The allocation and management of critical resources in rural China under restructuring: Problems and prospects. Journal of Rural Studies, 47: 392-412. https://doi.org/10.1016/j.jrurstud.2016.03.011

[4] Wang, R., Guo, Z.W., Cai, C.J., Zhang, J.F., Bian, F.Y., Sun, S.Y., Wang, Q.B. (2021). Practices and roles of bamboo industry development for alleviating poverty in China. Clean Technol. Environ. Policy, 23(6): 16871699. https://doi.org/10.1007/s10098-021-02074-3

[5] George, C., Yamaguchi, S. (2018). Assessing implementation of environmental provisions in regional trade agreements. Working Papers. Danvers, MA: OECD. https://doi.org/10.1787/91aacfea-en

[6] Ciriković, E. (2014). Marketing mix in tourism. Academic Journal of Interdisciplinary Studies, 3(2): 136144. http://dx.doi.org/10.5901/ajis.2014.v3n2p111

[7] Juandi, V.S., Andari, R., Setiyorini, H.P.D. (2017). The influence of sustainable tourism development towards tourists' satisfaction in Saung angklung Udjo the influence of sustainable tourism development towards tourists' satisfaction in Saung Angklung Udjo. in 1st UPI International Geography Seminar 2017, 145(1): 012020. http://dx.doi.org/10.1088/1755-1315/145/1/012020

[8] Li, P.H., Zhou, G.M., Du, H.Q., Lu, D.S., Mo, L.F., Xu, X.J., Shi, Y.J., Zhou, Y.F. (2015). Current and potential carbon stocks in Moso bamboo forests in China. $\mathbf{J}$ Environ $\quad$ Manage., 156 : 89-96. https://doi.org/10.1016/j.jenvman.2015.03.030

[9] Qin, Y.B., Xin, Z.B., Wang, D.M., Xiao, Y.L. (2017). Soil organic carbon storage and its influencing factors in the riparian woodlands of a Chinese karst area. CATENA, 153: 21-29. http://dx.doi.org/10.1016/j.catena.2017.01.031

[10] Gu, L., Wu, W.G., Ji, W., Zhou, M.J., Xu, L., Zhu, W.Q. (2019). Evaluating the performance of bamboo forests managed for carbon sequestration and other co-benefits in Suichang and Anji, China. Forest Policy Econ., 106: 101947. http://dx.doi.org/10.1016/j.forpol.2019.101947

[11] Lonn, P., Mizoue, N., Ota, T., Kajisa, T., Yoshida, S. (2018). Evaluating the contribution of community-based ecotourism (CBET) to house-hold income and livelihood changes: a case study of the Chambok CBET program in Cambodia. Ecol Econ., 151: 62-69. https://doi.org/10.1016/j.ecolecon.2018.04.036

[12] Pellikka, J. (2014). The Commercialization Process of Innovation in Small High Technology Firms. Theoretical Review, Bab Kedua dalam buku (sudah diterbitkan secara elektronik) Therin, Francois. Handbook of Research on TechnoEntrepreneurship. Chaltenham, UK: Edward Elgar. 2014.

[13] Renani, H.S., Manian, Z., Hoseini, M. (2016). Effective factors in commercialization of traditional arts in Isfahan from the perspective of activists in this field. Jurnal International Business Management, 10(16): 3380-3388. http://dx.doi.org/10.36478/ibm.2016.3380.3388

[14] Chutia, L.J.C., Sarma, M.K. (2016). Commercialization of traditional crafts of South East Asia: A conceptual model based on review of literature. Jurnal IIM Kozhikode Society \& Management Review, 5(2): 107119. https://doi.org/10.1177/2277975215624728

[15] Leandro, T.D., Shirasuna, R.T., Filgueiras, T.S., Scatena, V.L. (2016). The utility of Bambusoideae (Poaceae, Poales) leaf blade anatomy for identification and systematics. Brazilian Journal of Biology, 76(3): 708717. https://doi.org/10.1590/1519-6984.01715

[16] Yeasmin, L., Ali, M.N., Gantait, S., Chakraborty, S. (2015). Bamboo: An overview on its genetic diversity and characterization. 3 Biotech, 5(1): 1-11. https://doi.org/10.1007/s13205-014-0201-5

[17] Akwada, D.R., Akinlabi, E.T. (2016). Economic, social and environmental assessment of bamboo for infrastructure development. International Conference on Infrastructure Development in Africa, pp. 1-15.

[18] Pramono, R., Hidayat, J., Dharmawan, C., Sihombing, S.O., Maleachi, S. (2021). Opportunities for the development and promotion of traditional bamboo craft as tourism products. 20(2): 1-14.

[19] Amoah, M., Asomani, J., Dzakpasu, R.K., Asafuah, F. (2017). Gender-based differences in the commercialisation of rattan and bamboo as livelihood support option for rural and urban poor in Ghana: Opportunities and challenges. American Journal of Environmental and Resource Economics, 2(1): 1-11. https://doi.org/10.11648/j.ajere.20170201.11

[20] Creswell, J.W. (2014). Research Qualitative, Quantitative, and Mixed Methods Approaches Design Fourth Edition. SAGE Publications, Inc; 4th edition. 